\title{
REENGINEERING IN AUSTRALIA: FACTORS AFFECTING SUCCESS
}

\author{
Felicity Murphy \\ Simsion Bowles and Associates \\ Melbourne, Victoria \\ E-mail: fmurphy@sba.com.au \\ Sandy Staples \\ Department of Information Systems \\ The University of Melbourne \\ Parkville. Victoria \\ E-mail: s.staples@dis.unimelb.edu.au
}

\begin{abstract}
Business process rengineering (BPR) is being used in many organisations worldwide to realign operations. Most of the research undertaken has been focused on North American or European practices. The study reported here replicates a US reengineering study in an Australian context by surveying large public and private sector Australian organisations. The study makes three main contributions by: (1) presenting a picture of BPR practices in Australia, (2) clarifying factors critical to the success of reengineering projects in Australia, and (3) providing a comparison of factors leading to success in Australian BPR projects with those found in the US.
\end{abstract}

\section{KEYWORDS}

Business process reengineering (DD0402)

\section{INTRODUCTION}

It is clear when reading both academic and practitioner literature that business process reengineering (BPR) is an important phenomenon which has grown rapidly since the early 1990's. A survey of $500 \mathrm{ClO}$ 's conducted by the accounting firm, Deloitte and Touche, found that the average CIO was involved in 4.4 reengineering projects in 1993 up from 1.6 projects in 1992 (Moad 1993). Brancheau, Janz and Wetherbe (1996) found that top managers rated "Facilitating and managing business process redesign" as the second most important issue they faced in 1994/5. Although BPR has been recognised as an important phenomenon it has not always been an unqualified success. Hammer and Champy (1994) stated that between 50 and 70 percent of reengineering projects do not achieve the goals set out for them. Butler (1997), however, suggested that failure statistics quoted in the literature have decreased with time, as experience and education about process redesign has grown.

In the eight years since reengineering emerged, there has been some research done on the critical success factors but most of this work focused on North American or European practices (e.g., Grover, Jeong, Kettinger \& Teng 1995, Clemons, Thatcher \& Row 1995, Hall, Rosenthal \& Wade 1993, Miles, Coleman \& Creed 1995). In the Australian context, aside from the work done by Weill, Broadbent and Butler, (Broadbent \& Weill 1995, Broadbent et al. 1996, Butler 1993 \& 1997), there have been very few studies examining the impact of BPR. This suggests that the understanding of Australian BPR practices is limited and research is needed.

With this in mind we undertook a study in Australia that examined reengineering practices and critical success factors. Our study had two main objectives. First, we wanted to examine the impact of factors that the literature suggested could influence the success of reengineering practice in Australia. Second, we wanted to compare our findings with reengineering knowledge in the United States (US). Therefore, our two research questions were:

1. What are the critical success factors for BPR implementation in an Australian context?

2. How do the critical success factors for BPR implementation in Australia compare to US factors?

The severity of common problems associated with reengineering and the criticality of their impact on project success was assessed to answer the first question. To address the second question, we replicated Grover, Jeong, Kettinger, and Teng's (1995) US-based research. Grover et al. (1995) empirically examined the importance of 64 possible critical success factors as viewed by practitioners in 105 American organisations. The impact of the factors on perceived success was then tested. We did the same thing using the views of Australian reengineering practitioners. 
After reviewing various definitions of business process reengineering, we found that Grover et al.'s (1995) definition succinctly captured the key points of other authors and was therefore adopted for this study. Thus, the definition of BPR used in this study was:

A deliberate (planned) change, typically enabled by information technologies in an attempt to redesign a

business process to achieve performance breakthroughs in measures such as quality, speed, customer service, and cost.

The remainder of this paper is organised as follows. The next section summarises the literature about potential reengineering success factors. The third section describes the methodology used in our study. The fourth section presents the results. In the final section, the results are discussed and implications for practice and research are offered.

\section{A REVIEW OF FACTORS THAT POTENTIALLY IMPACT REENGINEERING SUCCESS}

A review of the literature was conducted to identify factors that writers and researchers suggested could potentially affect reengineering success. The results of this review, summarized below, are organised into six areas: management support, technological competence, process delineation, project planning, change management, and project management.

Management Support: Management support and leadership in reengineering efforts has been identified in much of the literature as perhaps the most significant contributing factor to the success of an initiative. Top management support is necessary to develop faith throughout the organisation in the project and a respect for the project team (Hall et al. 1993, Hammer \& Stanton 1995, Hoopes 1995). Grover et al. (1995) identified a group of implementation problems regarding management support. The results of their survey found that while management support problems were "severe" (Grover et al. 1995) (interpreted as difficult to address), they did not correlate highly with the overall measure of success in comparison to other implementation problems. They concluded that the resolution of these problems was a necessary but not sufficient condition for project success.

Technological Competence: Information technology is referenced in much of the literature as the enabler of the change to a process orientation. Grint, Case and Willcocks (1995) conducted a survey and found that 58 percent of respondents rated IT's role in enabling radical process redesign as critical, 68 percent rated IT's support role in redesign as critical, and IT management was rated as one of the top ten critical success factors for BPR projects. IT can be the enabler of change but it can also be a potential constraint as most firms have existing IT infrastructures built up over many years (Hammer 1990, Taylor 1996). The state of the IT infrastructure can influence the choice of process to reengineer and the choice of either a radical or an incremental implementation plan (Broadbent \& Weill 1995). The human component of technological competence, in terms of the level of IT knowledge, experience and expertise within the organisation, also needs to be addressed when implementing change (Martinez 1995). The results of the Grover et al. (1995) study suggests that taking good care of the required technology may be necessary but not sufficient for the eventual success of reengineering projects.

Process Delineation: Process delineation entails defining the scope of the process, identifying process owners, identifying the implementation strategy to be used and establishing goals for the redesigned process (Grover et al. 1995). Redesign projects often aim at processes that are "too narrowly defined and therefore have little discernible impact on overall performance" (Hall et al. 1993:121). The scope of the process chosen for redesign must be broadly defined in terms of cost improvements or increases in customer value for it to improve performance across the organisation. Redesign projects can also be defined too radically with changes being too wide for organisations to cope with (Davenport 1993, Martinez 1995). Process delineation should be undertaken carefully after having assessed the organisations resources and it should involve the identification of performance improvement goals for the redesigned process (Clemons 1995, Miles et al. 1995). Grover et al. (1995) argued that while process delineation problems may not be difficult to address they have a significant impact on project outcomes.

Project Planning: Project planning as defined by Grover et al. (1995) consists of strategic and tactical planning. Strategic planning concerns the organisational vision and strategy for the future whereas tactical planning concerns the plan for the implementation of the single change project being undertaken. The project initiative should "be driven by corporate strategy and supported at the highest levels of the organisation. Ultimately it must make daily operations themselves the execution of strategy." (Manganelli \& Raspa 1995). Tactical project planning focuses largely on the reengineering team and the resources and authority that are placed at its disposal. The quality of resources and the amount of authority given to the project team indicate to the rest of the organisation the level of importance and management support the project is receiving. The resources 
that reengineering teams require include human (i.e., having the most highly skilled and knowledgeable people); financial (e.g., money for new IT or other expenses); training for team members; and, in some cases, a consultant to provide expert advice (Hammer \& Champy 1994, Hammer \& Stanton 1995, Keen 1995, Miles et al. 1995).

Change Management: Manganelli and Raspa (1995:42) note that "because change can be intimidating a fair amount of anxiety usually surfaces when a reengineering project is announced." In the Grover et al. (1995) study, change management issues emerged as the set of problems with the most significant negative relationship with project outcome. One of the methods suggested for mitigating the resistance to change is the communication of the vision behind the impending change. It is suggested in much of the literature (Davenport 1993, Grint et al. 1996, Hall et al. 1993) that the reasons and expectations for the change should be communicated organisation-wide as a way of motivating people and enticing them to commit themselves to the project. Stoddard and Jarvenpaa (1995:104) comment, "you always underestimate the amount of communication you have to do. Always triple what you think it takes." Involving the entire organisation in the change process is a good way to overcome lethargy and resistance within the organisation (Romney 1996). Human resource issues also need consideration when an organisation undergoes change (Davenport 1993, Hall et al. 1993, Hammer \& Champy 1994, Romney 1994). Incentive and reward structures, new skills training, and other human resource policies may require alteration in response to the organisational restructuring. It is important that this is addressed if management wishes to cultivate the required values towards the reengineering project.

Project Management: Project management refers to the level of skills and experience senior management and reengineering teams have in managing large-scale projects. Managing projects entails assessing performance throughout the project life span, assigning team members responsibility to the projects and managing the communication both within the project team and between the team and the rest of the organisation. Poor project management can have a significantly negative impact on the success of reengineering projects (Hammer \& Stanton 1995, Martinez 1995). The Grover et al. (1995) study found that although project management problems were not difficult to rectify they were highly influential on the outcome of the project. The lack of a recognised or appropriate BPR methodology to guide managers in implementation is also a problem that has been identified widely in the BPR literature (Davenport 1993, Grint et al. 1996, Grover et al. 1995).

The results of this review suggest that there are many important factors to consider when implementing a BPR program. These projects are difficult to manage and success is difficult to attain. The next section discusses the methodology we used to examine potential success factors in Australian reengineering practice.

\section{METHODOLOGY}

A quantitative research design was chosen to examine the importance of the success factors and their relationship to perceived success. A questionnaire was used in order to facilitate collection of information from a large and geographically disperse sample. This section describes the measures used, sampling method, and analysis methods employed.

\section{Measurement}

After reviewing the BPR literature, it was found that the list of 64 potential BPR implementation problems presented by Grover et al. (1995) covered the area concisely; thus, this list of factors was adopted for our study. Grover et al. (1995) reviewed literature in the areas of organisational change, innovation, organisational development and socio-technical design, as well as the BPR literature to identify these factors. The 64 items are listed in Table 1. Grover et al. (1995) suggested that the 64 questions could be collapsed into six constructs: management support, technological competence, process delineation, project planning, change management, and project management.

The management support construct measured the level of support, understanding, and leadership which senior management exhibited towards the reengineering project and was measured using 6 items. The technological competence construct assessed the existence and use of the organisations' IT infrastructure, in terms of both hardware, software, and human components, which supported or enabled the reengineering effort. This construct was measured using 8 items. The process delineation construct measured the depth and breadth of the process chosen and the goals established for reengineering, and was measured using 8 items. The construct of project planning was addressed using 13 items which tapped the conduct of the project and the integration of the project with plans or strategies for the organisation as a whole. The change management construct measured the prevalence of resistance to change, the implementation of management systems to garner support for the reengineering effort, and the attitudes of groups within the organisation to the reengineering project (16 items). The construct of project management was measured using 13 items assessing the management of the project in terms of the human 
resources, the skill set required to implement reengineering, and the implementation of project performance measurement structures. The dependent variable adopted for our study and used in the analysis of the Grover et al. (1995) items was perceived project success. Perceived success, measured by one five-point scale question, is according to DeLone and McLean (1992) the most widely used measure of MIS success.

\section{Sample}

A nation-wide mail survey of Australian organisations was conducted. The questionnaire was distributed to senior managers of the 1000 top Australian companies (chosen on the basis of revenue) in the private or public sectors via a mailing list purchased from Drake List Management Services. The questionnaire package contained a cover letter addressed to the senior manager asking him/her to pass the enclosed questionnaire on to a project leader of a recent reengineering project. Both the senior manager and the project leader were offered a report of the findings of the study in an attempt to motivate them to respond. To increase the response rate, a reminder letter was sent to senior managers of non-responding organisations about three weeks after mailing the questionnaire package.

The Grover et al. (1995) study consisted of project specific questions and as such required the respondent to focus on and answer in the context of a single chosen project. To be consistent with the Grover et al. (1995) study, our questionnaire was directed to a project leader. The unit of analysis in this survey was therefore, a single process redesign project. This was consistent with our objectives of examining factors that lead to project success and was consistent with the unit of analysis used by Grover et al. (1995).

Of the 1000 surveys sent, 196 people indicated that they had not undertaken reengineering (an option we provided in the covering letter) and 104 returned a completed questionnaire. Therefore, our response rate was 30.0 percent. The potential for non-response bias was addressed by profiling both early and late responders and comparing the two groups according to techniques described by Fowler (1993). This analysis yielded no significant differences between the groups and supports the position that non-response bias did not appear to be a problem.

On average, respondents had been employed with the current organisation for 10.15 years and reported having an average of 5.19 years and 4.5 projects worth of experience with reengineering. Reengineering training had been received by only 31 percent of the project leaders. The average project length was reported as approximately 1 year and 9 months. The business areas that were the focus of reengineering consisted of a single business division in 29.7 percent of cases, two or more divisions in 32.7 percent of cases, and organisation-wide in 37.6 percent of cases. Consultants were used in 63 percent of the reported projects and the consultant input into the reengineering exercise was generally regarded as valuable. The reengineering projects were considered reasonably successful.

\section{Analysis}

The 64 potential problem items adopted from the Grover et al. (1995) study were analysed using the same techniques as the Grover study, to facilitate comparison. Respondents rated the 64 problem items on a 5-point Likert scale in terms of the perceived relative severity of the problem in their last reengineering project. The severity score for each problem was calculated as the percentage of respondents who rated it as either a major problem or an extreme problem (i.e. 4 or 5 on the 5point scale). The responses were re-coded to reflect a 0 for answers of 1,2 , or 3 (i.e. not a problem) and a 1 for answers of 4 or 5 (i.e. a problem); this was the items severity score. The problems were then ranked in terms of their average severity scores. For example, the severity score for the first item in Table 1 indicates that approximately $44 \%$ of our respondents had difficulty in finding skilled team members during their last BPR project.

Reliability of the items that addressed each construct was assessed via Cronbach's alpha. The items for each construct were then summed to create a mean severity score. Not all items were used to create the construct severity scores. To be comparable to Grover et al.'s (1995) work, we chose to use the same items to measure the constructs (see Table 2). These items were identified in Grover et al.'s study via factor analysis. Principal component analysis with varimax rotation was used in our study to test the validity of the constructs and confirm that the choice of using the Grover et al. items was reasonable.

The severity scores were then correlated with perceived project success in order to assess the impact of the factors on project success, thus answering our first research question. To address our second research question, the mean severity scores that we obtained were compared to the results found by Grover et al. (1995) in their study of US reengineering practice. 


\section{RESULTS}

Table 1 summarises the rankings obtained from the respondents in our sample and compares the severity scores and rankings of each of the problem items with the scores and rankings found in the US study (Grover et al. 1995). The severity scores for the Australian replication were much higher than those found in the Grover et al. (1995) study (i.e. the highest severity score in the US being 31.8 while the highest Australian score was 44 ). While the items did not appear to be ranked similarly at first glance they were in fact significantly correlated with the Grover et al. (1995) scores (Pearson correlation coefficient $=0.604$, $\mathrm{p}<.001$ ).

Factor analysis was done to assess the validity of the construct measures and compare the results with the Grover et al. (1995) study. We found some differences but these were largely for constructs that had numerous items. For the factors with fewer items (i.e. technological competence, management support) the results were similar to the Grover et al. (1995) study. The relatively small sample size in our study made the stability of our factor analysis results questionable. Due to the general similarities in factors between the Grover et al. (1995) study and our results and in the interests of making the replication as accurate and comparable as possible we chose to use the items selected by Grover et al. (1995) to measure the constructs for the balance of the analysis.

The Grover et al. (1995) factor analysis stabilised at nine factors which we used in our analysis (see Table 2). Three constructs were found to be multi-dimensional. The project planning items broke into two factors: strategic planning and tactical planning. The change management items also broke into two factors: human resources and change management. A second factor, dealing with time frame problems, also broke out of the list of project management items. The Cronbach's alpha values indicate that the constructs have a reasonable degree of internal consistency supporting the validity of the nine factors.

The average severity scores for the problem categories/constructs were calculated by averaging the percentage severity scores (see Table 1) for the items chosen to represent that construct. The resulting mean severity score for the problem category (i.e., construct) was compared to the Grover et al. (1995) score (Table 2). The rankings of the Australian problem category severity scores were not significantly correlated with the US severity scores (Spearman's Rho $=0.300, p=0.433$ ).

The average severity scores from our study for each problem category were correlated with the perceived success measure (see the last column of table 2). All of the factors except Technological Competence were significantly correlated with perceived project success. The next section discusses the findings. 
Table 1: Severity rankings for the 64 problem items

\begin{tabular}{|c|c|c|c|c|c|c|}
\hline & Question & Category & $\begin{array}{l}\text { Australia } \\
\text { Severity }\end{array}$ & $\begin{array}{c}\text { US } \\
\text { Severity }\end{array}$ & $\begin{array}{l}\text { Aust. } \\
\text { Rank }\end{array}$ & $\begin{array}{c}\text { US } \\
\text { Rank }\end{array}$ \\
\hline 1 & $\begin{array}{l}\text { Difficulty in finding business reengineering team members who } \\
\text { have required skills and knowledge }\end{array}$ & PP & 44 & 12.5 & 1 & 45 \\
\hline 2 & Difficulty in gaining cross-functional co-operation & $\mathrm{CM}$ & 41 & 20.1 & 2 & 20 \\
\hline 3 & Top management's short-term view and quick-fix mentality & PP & 41 & 31.7 & 2 & 2 \\
\hline 4 & The business reengineering effort takes too much time & PM & 38 & 23.1 & 4 & 9 \\
\hline 5 & $\begin{array}{l}\text { Unreasonable expectations attributed to business process } \\
\text { reengineering as a solution for all organisational problems }\end{array}$ & $\overline{\mathrm{CM}}$ & 38 & 22.1 & 4 & 12 \\
\hline 6 & Line managers in the organisation unreceptive to innovation & $\overline{\mathrm{CM}}$ & 37 & 28.8 & $\overline{6}$ & 4 \\
\hline 7 & $\begin{array}{l}\text { Necessary changes in the human resource policies for business } \\
\text { reengineering implementation were not made }\end{array}$ & $\mathrm{CM}$ & 37 & 15.9 & 6 & 34 \\
\hline 8 & $\begin{array}{l}\text { Top management's insufficient understanding about business } \\
\text { reengineering }\end{array}$ & MS & 35 & 15.4 & 8 & 36 \\
\hline 9 & $\begin{array}{l}\text { Absence of management systems (e.g. incentive, training system) } \\
\text { to cultivate required values }\end{array}$ & $\mathrm{CM}$ & 34 & 20.6 & 9 & 18 \\
\hline 10 & $\begin{array}{l}\text { Lack of appropriate employee compensation incentives in the new } \\
\text { process }\end{array}$ & $\mathrm{CM}$ & 34 & 16.8 & 9 & 26 \\
\hline 11 & Limited IS application infrastructure & $\mathrm{TC}$ & 34 & 18.6 & 9 & 22 \\
\hline 12 & $\begin{array}{l}\text { Failure to commit the required resources (financial, human } \\
\text { resources, etc.) to business reengineering efforts }\end{array}$ & PP & 33 & 17.6 & 12 & 25 \\
\hline 13 & Lack of senior management leadership for reengineering efforts & MS & 32 & 16.3 & 13 & 29 \\
\hline 14 & Difficulty in measuring reengineering project performance & PM & 32 & 21.1 & 13 & 17 \\
\hline 15 & Uncertainty about the reengineering project's time-frame & $\mathrm{PM}$ & 30 & 22.1 & 15 & 12 \\
\hline 16 & $\begin{array}{l}\text { Failure to anticipate and plan for organisational resistance to } \\
\text { change }\end{array}$ & $\mathrm{CM}$ & 29 & 27.7 & 16 & 5 \\
\hline 17 & Failure to build support from line managers & $\mathrm{CM}$ & 29 & 23 & 16 & 10 \\
\hline 18 & $\begin{array}{l}\text { Inadequate training for personnel affected by the redesigned } \\
\text { process }\end{array}$ & $\mathbf{C M}$ & 28 & 16.9 & 18 & 33 \\
\hline 19 & Lack of alignment between corporate planning and IT planning & $\mathrm{PP}$ & 28 & 23.3 & 18 & 7 \\
\hline 20 & Limited database infrastructure & TC & 27 & 22.2 & 20 & 11 \\
\hline 21 & Not enough time to develop new skills for the redesigned process & $\overline{\mathrm{CM}}$ & 27 & 7 & 20 & 60 \\
\hline 22 & $\begin{array}{l}\text { Difficult to forecast human resources, financial, and other } \\
\text { resource requirements }\end{array}$ & PD & 26 & 13.6 & 22 & 39 \\
\hline 23 & Ambiguity in job expectations for reengineering team members & PM & 26 & 12.5 & 22 & 45 \\
\hline 24 & Rigid hierarchical structures & $\mathrm{CM}$ & 26 & 30.1 & 22 & 3 \\
\hline 25 & Senior management's failure to commit to new values & $\mathrm{CM}$ & 26 & 18.5 & 22 & 23 \\
\hline 26 & Need for managing change is not recognised & $\mathrm{CM}$ & 26 & 31.8 & 22 & 1 \\
\hline 27 & $\begin{array}{l}\text { Difficulty in financially justifying benefits of business } \\
\text { reengineering }\end{array}$ & $\mathrm{PP}$ & 25 & 13.6 & 27 & 39 \\
\hline 28 & $\begin{array}{l}\text { Failure to assess project performance in the early stages of } \\
\text { business reengineering efforts to provide feedback }\end{array}$ & $\mathrm{PM}$ & 25 & 8.9 & 27 & 54 \\
\hline 29 & $\begin{array}{l}\text { Manager's failure to support the new values and beliefs demanded } \\
\text { by the redesigned processes }\end{array}$ & MS & 24 & 21.7 & 29 & 16 \\
\hline 30 & $\begin{array}{l}\text { Insufficient understanding about the goals of top management in } \\
\text { relation to business reengineering }\end{array}$ & $\mathrm{MS}$ & 24 & 18.2 & 29 & 24 \\
\hline 31 & Insufficient understanding about existing data, applications, and & TC & 23 & 25.3 & 31 & 6 \\
\hline
\end{tabular}


IT across the organisation

T. PD - Process Delineation; PM - Project Management; PP - Project Planning; CM - Change Management; TC Technological Competence; MS - Management Support

Table 1 continued: Severity rankings for the 64 problem items

\begin{tabular}{|c|c|c|c|c|c|c|}
\hline & Question & Category & $\begin{array}{c}\text { Australia } \\
\text { Severity }\end{array}$ & $\begin{array}{c}\text { US } \\
\text { Severity }\end{array}$ & $\begin{array}{l}\text { Aust. } \\
\text { Rank }\end{array}$ & $\begin{array}{l}\text { US } \\
\text { Rank }\end{array}$ \\
\hline 32 & $\begin{array}{l}\text { Difficulty in modelling and simulating the proposed change to the } \\
\text { business process }\end{array}$ & PM & 23 & 8.9 & 31 & 54 \\
\hline 33 & Lack of experience in business reengineering & PP & 23 & 20.2 & 31 & 19 \\
\hline 34 & Failure to aggressively use IT enablers & TC & 23 & 16.6 & 31 & 27 \\
\hline 35 & Lack of top management support in business reengineering efforts & MS & 23 & 13.5 & 31 & 41 \\
\hline 36 & $\begin{array}{l}\text { Failure to consider the politics of the business reengineering } \\
\text { efforts }\end{array}$ & $\mathrm{CM}$ & 22 & 23.3 & 36 & 7 \\
\hline 37 & Lack of business reengineering project champion & MS & 22 & 8.7 & 36 & 56 \\
\hline 38 & $\begin{array}{l}\text { Focusing only on evaluation criteria that are easily measurable and } \\
\text { quantifiable }\end{array}$ & PD & 21 & 12.9 & 38 & 43 \\
\hline 39 & Failure to consider existing organisational culture & $\mathrm{CM}$ & 20 & 15.4 & 39 & 36 \\
\hline 40 & $\begin{array}{l}\text { Lack of IS participation and assistance in the reengineering } \\
\text { project }\end{array}$ & TC & 20 & 13.5 & 39 & 41 \\
\hline 41 & Failure to continually assess emerging IT capabilities & TC & 20 & 14.5 & 39 & 38 \\
\hline 42 & $\begin{array}{l}\text { Reengineering team members' conflict between the team } \\
\text { responsibilities and functional responsibilities }\end{array}$ & PM & 20 & 16.4 & 39 & 28 \\
\hline 43 & Lack of authority given to reengineering team & PP & 20 & 16.3 & 39 & 29 \\
\hline 44 & Lack of expertise in IT in your organisation & TC & 20 & 19.5 & 39 & 21 \\
\hline 45 & $\begin{array}{l}\text { Failure to communicate reasons for change to members of the } \\
\text { organisation }\end{array}$ & $\mathrm{CM}$ & 19 & 16.3 & 45 & 29 \\
\hline 46 & Lack of strategic vision & PP & 19 & 22.1 & 45 & 12 \\
\hline 47 & Difficulty in gaining control of reengineering efforts & PM & 19 & 9.7 & 45 & 53 \\
\hline 48 & $\begin{array}{l}\text { Difficulty in establishing performance-improvement goals for the } \\
\text { redesigned process }\end{array}$ & PD & 18 & 22.1 & 48 & 12 \\
\hline 49 & $\begin{array}{l}\text { Failure to effectively monitor progress of project according to the } \\
\text { schedule }\end{array}$ & $\overline{\mathrm{PM}}$ & 18 & 11.6 & 48 & 47 \\
\hline 50 & Lack of appropriate BPR methodology & PM & 17 & 5.8 & 50 & 61 \\
\hline 51 & $\begin{array}{l}\text { Failure to identify process owners who are responsible for entire } \\
\text { business processes }\end{array}$ & $\mathrm{PD}$ & 16 & 16.3 & 51 & 29 \\
\hline 52 & Absence of appropriate training for BPR team members & $\mathrm{PP}$ & 15 & 8.7 & 52 & 56 \\
\hline 53 & $\begin{array}{l}\text { Proposed changes to the process were too incremental, not radical } \\
\text { enough }\end{array}$ & $\mathrm{PD}$ & 15 & 10.6 & 52 & 50 \\
\hline 54 & $\begin{array}{l}\text { Poor communication between reengineering team members and } \\
\text { other organisational members }\end{array}$ & $\overline{\mathrm{PM}}$ & 15 & 15.6 & 52 & 35 \\
\hline 55 & Too much emphasis on analysing the existing process & PM & 15 & 8.6 & 52 & 58 \\
\hline 56 & Limited telecommunication infrastructure & $\mathrm{TC}$ & 13 & 11.6 & 56 & 47 \\
\hline 57 & $\begin{array}{l}\text { Failure to understand customers' viewpoints in the business } \\
\text { reengineering efforts }\end{array}$ & $\mathrm{PP}$ & 12 & 7.8 & 57 & 59 \\
\hline 58 & Lack of appropriate planning & PP & 12 & 10.6 & 57 & 50 \\
\hline 59 & $\begin{array}{l}\text { Failure to include process owners throughout the business } \\
\text { reengineering effort }\end{array}$ & PD & 11 & 10.7 & 59 & 49 \\
\hline 60$]$ & $\begin{array}{l}\text { Lack of external-consultant support for business reengineering } \\
\text { efforts }\end{array}$ & PP & 10 & 3.9 & 60 & 66 \\
\hline
\end{tabular}




\begin{tabular}{|l|l|c|c|c|c|c|}
\hline 61 & Scope of reengineered process was defined inappropriately & PD & 10 & 10.6 & 60 & 50 \\
\hline 62 & $\begin{array}{l}\text { Identification of candidate process for reengineering not based on } \\
\text { strategic planning }\end{array}$ & PP & 10 & 12.6 & 60 & 44 \\
\hline 63 & Poor communication among reengineering team members & PM & 8 & 4.8 & 63 & 62 \\
\hline 64 & Approach to reengineering was too radical & PD & 7 & 2.9 & 64 & 64 \\
\hline
\end{tabular}

1. PD - Process Delineation; PM - Project Management; PP - Project Planning; CM - Change Management; TC -

Technological Competence; MS - Management Support

Table 2: Severity and Ranking of Reengineering Problems in Australia versus US

\begin{tabular}{|c|c|c|c|c|c|c|c|}
\hline Construct Label & $\begin{array}{r}\text { Items from } \\
\text { used to Me } \\
\text { Constrn }\end{array}$ & $\begin{array}{l}\text { fabtednbach's } \\
\text { qasure } \\
\text { ctt }\end{array}$ & Alphastralian & $\begin{array}{r}\text { Ranktralian S } \\
\text { Score } \\
\text { Constru } \\
\end{array}$ & $\begin{array}{l}\text { JevefHyank ( } \\
\text { for et al. } 19 \\
\text { ets }\end{array}$ & $\begin{array}{l}\text { Grbiseseverit } \\
\text { 95) }\end{array}$ & $\begin{array}{l}\text { So6melation with } \\
\text { Perceived Success }\end{array}$ \\
\hline Human Resource & $9,18,2$ & .71 & 1 & 31.0 & 6 & 14.8 & .264난 \\
\hline Management Su & propt 3, 29, 30 & $35,37 \quad .84$ & 2 & 27.3 & 5 & 15.6 & $316^{*}$ \\
\hline Change Manage & $\begin{array}{r}\operatorname{men} \theta, 16,25 \\
45 \\
\end{array}$ & $26,36, \quad .83$ & 3 & 27.1 & 1 & 21.9 & $.366^{*}$ \\
\hline Time Frame & $4,15,32$ & .67 & 4 & 24.8 & 4 & 16.4 & $.418 *$ \\
\hline $\begin{array}{l}\text { Technological } \\
\text { Competence }\end{array}$ & $\begin{array}{r}11,40,31, \\
44,5 \\
\end{array}$ & $\$ 0,34, \quad .85$ & 5 & 22.9 & 2 & 18.2 & .202 \\
\hline Project Manage & $\begin{array}{r}\text { nent, } 15,28 \\
54\end{array}$ & 47,50 & 6 & 21.2 & 8 & 11.7 & $.392 *$ \\
\hline Tactical Plannin & g $12,27,52$, & $\$ 7,60$ & 7 & 18.4 & 9 & 10.3 & $.375 *$ \\
\hline Strategic Planni申 & g $19,46,5$ & $\$, 62$ & 8 & 17.8 & 3 & 17.2 & $.307 *$ \\
\hline Process Delinea & $\begin{array}{r}1082,48,51, \\
61\end{array}$ & $3,59, \quad .76$ & 9 & 17.0 & 7 & 14.0 & $.429 *$ \\
\hline
\end{tabular}

Perceived project success was measured one a 5 point scale ranging from $1=$ success to $5=$ failure.

\section{DISCUSSION}

The first research question we sought to address was what factors appear to significantly impact the success of Australian reengineering projects. Eight of the nine constructs were significantly associated with success. The only construct not significantly related to success was technological competence (although about 23 percent of projects had problems in this category). Consistent with this, only two technology-related problems were in the top twenty list (Table 1). These findings reinforce the notion of a shift in focus away from an IT-centric approach to a more holistic approach to restructuring. IT appears to be an important enabler, not a driver of organisational change and restructuring.

The two change management constructs ranked number one and three in terms of being a problem for Australian BPR project leaders and both were significantly associated with success. This implies that change management issues are not only common problems in BPR projects (i.e., present in roughly 30 percent of projects), but they are important problems to resolve since if they are not resolved, the likelihood of success declines. Consistent with this, six of the top ten problem items in Table 1 were change management issues. Establishing cross-function cooperation, setting reasonable expectations for the project, and aligning incentive and reward systems with new processes and directions were all found to be common problems. These are clearly important problems for management to focus on and solve.

The management support construct ranked second in terms of problem severity (i.e., occurred in about 27 percent of projects) and was significantly correlated with perceived success. This implies that a lack of management support remains a severe problem and it has a significant negative impact on success. While it has been suggested that the Australian BPR push has come almost entirely from general management (Simsion, 1997), the results of our study indicate that there may still be a lack of high level management support for reengineering. Perhaps if the initial push comes from management, their support and leadership does not last long enough. Respondents reported that the average time taken for a project was 1.75 years. Management must have a realistic time frame in mind when initiating these types of projects and be willing to provide support and energy for the life of the project. The fact that the fourth most severe problem construct dealt with issues of timing, such as the project taking too long and uncertainty about the project's time frame, also suggests that managing the timing of the project and setting realistic expectations are common problems that are critical for project success. 
Planning issues, both tactical and strategic, were experienced by about one-fifth of the project managers in our study, as were problems dealing with defining the process. While not as common as the problems described above, these groups of problems were still found to be significantly correlated with success so managers should not ignore these issues either.

Comparing the findings of the US-based Grover et al. (1995) study with our Australian results addresses the second research question. Marked differences were found between the rankings of severity found by Grover et al. (1995) in the US and the rankings that emerged in the Australian study. Some of the factors that were considered the most severe in the US study (for example technological competence and strategic planning, ranking 2 and 3 respectively) were not found to be as severe problems in the Australian context (ranking 5 and 8 respectively). However, just looking at the ranking can be somewhat misleading. The severity scores indicate the percentage of respondents who found problems in those areas. For example, strategic planning was a problem in about 18 percent of Australian projects (ranked 8th) and it was a problem for about 17 percent of US projects (ranked 3rd). In terms of frequency, they are quite similar.

The most striking difference in our view was that the results suggest that Australian BPR projects have about twice as many human resource and management support problems than do US projects. Possible explanations for this such as the US projects having more resources and support come to mind. Overall, the differences between the rankings from the US and the Australian studies, reported here, were greater than we expected. It is generally recognised that cultural and economic differences between Australia and the US are not great; hence, the differences in the results surprised us. Future research to investigate why these differences exist would be useful, and would perhaps find lessons from US practice that Australian practice could benefit from.

Although we tried to replicate the US study closely, the differences could also be potentially caused by two methodological factors. The first factor which could contribute to the differences in results is the time difference between the two studies. The Grover et al. (1995) paper was published in the Journal of Management Information Systems in 1995, which implies that the data set was probably collected in 1993. Much has been written and learnt about BPR in the four years since the Grover et al. (1995) data was collected. Consultant input in reengineering projects has also probably increased and the knowledge and experience base about best practices for reengineering in industry has grown. Respondents may now have a better grasp and awareness of problems that were previously regarded as severe.

Differences in the samples may be a second factor contributing to the variation. The respondents for the Grover et al. (1995) study were members of "the Planning Forum", which is the international business organisation focusing on strategic management and planning. Planning Forum members were selected because of their high interest and involvement in BPR projects (Grover et al. 1995). This may have contributed to differences in the results as these respondents are trained to think in terms of strategy, and possibly have more experience and knowledge about programs of corporate restructuring and change management issues. The respondents in our study were project leaders who may have had a different perspective.

As with all research, our work has a number of limitations. In our questionnaire, respondents were required to cast their minds back in order to answer many of the questions. The ability of the respondents to recall past events could potentially lead to errors. Our study also relied on respondent perceptions. Using a survey and perceptual measures is problematic because it introduces the potential for bias; however, for this research a mail survey was the most effective way to reach a large number of geographically dispersed respondents.

We see several potentially important contributions of this study. The research extends the knowledge base on critical success factors for business process reengineering in Australia. One purpose of this study was to replicate the Grover et al. (1995) instrument and compare the conclusions drawn in the two studies. This comparison has highlighted several differences between the nature of reengineering in Australia and the relationship between reengineering implementation problem severity and the impact of problems on success.

The Grover et al. (1995) instrument was also replicated with a view to validating it for use in future investigations of critical success factors for reengineering implementation. The factor analysis undertaken in the replication lends support to the validity of the instrument, although we would like to see the Grover et al. (1995) instrument tested with larger samples in future research. Ideally, all 64 items should be factor analysed together to test discriminant and convergent validity; we were unable to do this in our study due to sample size limitations. Future research such as this would help verify how to collapse the list of 64 items into valid constructs.

In conclusion, we found that reengineering was a practice being undertaken by a significant portion of Australian organisations. Reaping maximum gains from BPR projects is challenging, as shown by the prevalence and variety of problems identified in this study. We hope this study provides advice to practitioners on the factors to pay attention to in order to maximise the chance of a successful BPR implementation and hope it provides a base for future research on Australian reengineering practice. 


\section{ACKNOWLEDGEMENTS}

The authors gratefully acknowledge the insightful advice and suggestions from Peter Seddon of The University of Melbourne and from the anonymous reviewer. We would also like to thank Ravi Patnayakuni of The University of Melbourne, for his financial support and encouragement of this work.

\section{REFERENCES}

Brancheau, J. C., Janz, B. D. and Wetherbe, J. C. (1996) Key issues in information systems management 1994-95 SIM Delphi results. MIS Quarterly, 20:2, 225-242.

Broadbent, M. and Weill, P. (1995). Busting up the Business: Different approaches to Business Process Redesign and IT Infrastructure Investments. MIS (Australia), 42-48.

Broadbent, M., Weill, P. and St. Clair, D. (1996). The implications of IT infrastructure for business process redesign. Melbourne Business School, The University of Melbourne: Melbourne.

Butler, C. (1993). The role of information technology in business process redesign: observations from the literature. Melbourne Business School, University of Melbourne: Melbourne.

Butler, C. (1997). Business Process Redesign: The Australian experience. Melbourne Business School, University of Melbourne: Melbourne.

Clemons, E. K. (1995) Using scenario analysis to manage the strategic risks of reengineering. Sloan Management Review, $36: 4,61-71$.

Clemons, E. K., Thatcher, M. E. and Row, M. C. (1995) Identifying sources of reengineering failures A study of the behavioral factors contributing to reengineering risks. Journal of Management Information Systems, 12:2, 9-36.

De Lone, W. and McLean, E. R. (1992) Information systems success: the quest for the dependent variable. Information Systems Research, 3:1, 60-95.

Fowler, F. J. J. (1993) Survey research methods. Sage Publications: Newbury Park.

Grint, K., Case, P. and Willcocks, L. (1996) Business process reengineering reappraised: the politics and technology of forgetting. In Orlikowski, W. J., (Ed.) Information technology and changes in organizational work: proceedings of the IFIP WG8.2 Working Conference on Information Technology and Changes in Organizational Work, December 1995, . Chapman \& Hall on behalf of the International Federation for Information Processing (IFIP); London.

Grover, V., Jeong, S. R., Kettinger, W. J. and Teng, J. T. C. (1995) The implementation of business process reengineering. Journal of Management Information Systems, 12:1, 109-144.

Hall, G., Rosenthal, J. and Wade, J. (1993) How to make reengineering really work. Harvard Business Review, 71:6, 119131.

Hammer, M. (1990) Reengineering Work: Don't Automate Obliterate. Harvard Business Review, 68:4, 104-112.

Hammer, M. and Stanton, S. A. (1994) The reengineering revolution: a handbook. Harper Business: New York.

Hammer, M. and Champy, J. (1993) Reengineering the corporation : a manifesto for business revolution. Nicholas Brealey Publishing, Allen \& Unwin: London: St. Leonards, N.S.W.

Hoopes, J. (1995) Western civilisation versus the flat organisation. In Burke, G. and Peppard, J., (Eds.); Examining business process re-engineering: current perspectives and research directions, Kogan Page, London.

Keen, M. (1995) BPR: managing the change process - or the process of change managing BPR? In Burke, G. and Peppard, J., (Eds.); Examining business process re-engineering: current perspectives and research directions, Kogan Page, London.

Manganelli, R. L. and Raspa, S. P. (1995) Why reengineering has failed. Management Review, 84:7, 39-43.

Martinez, E. V. (1995) Successful reengineering demands IS/business partnerships. Sloan Management Review, 36:4, 5160.

Miles, R. E., Coleman, H. J., Jr. and Creed, W. E. D. (1995) Keys to success in corporate redesign. California Management Review, 37:3, 128-145.

Moad, J. (1993). Does reengineering really work? Datamation.

Pedhazur, E. J. and Schmelkin, L. P. (1991) Measurement, design, and analysis : an integrated approach. Lawrence Erlbaum Associates: Hillsdale, N.J.

Romney, M. (1994) Business process re-engineering. CPA Journal, 64:10, 30-32. 
Romney, M. (1996) Has reengineering left you financially stronger? CPA Journal, 66:1.

Simsion, G. (1997) New life for BPR. Management Information Systems, July.

Stoddard, D. B. and Jarvenpaa, S. L. (1995) Business process redesign Tactics for managing radical change. Journal of Management Information Systems, 12:1, 81-107.

Taylor, J. A. (1995) Don't obliterate informate! BPR for the information age. New Technology Work and Employment, $10: 2,82-88$. 